\title{
Protein-Hydrocarbon Interactions
}

\author{
INTERACTIONS OF VARIOUS PROTEINS WITH DECANE IN THE \\ PRESENCE OF ALCOHOLS
}

\author{
BY R. CECIL AND C. F. LOUIS \\ Department of Biochemistry, University of Oxford, Oxford OX1 3QU, U.K.
}

(Received 21 November 1969)

\begin{abstract}
1. Solutions of proteins were subjected to gentle agitation in the presence of small quantities of decane containing different alcohols. 2. Some of the protein was lost from solution and adsorbed on the surface of the emulsion formed; at the same time some decane was bound to the protein remaining in solution. 3. Comparison of these results with those obtained with pure decane suggests that a mixed film of protein + alcohol is formed on the surface of the emulsion. 4. If the concentration of alcohol in decane is increased the amount of protein adsorbed on the emulsion is decreased. This phenomenon was used to compare the effect of different alcohols in disrupting the hydrophobic interactions between proteins and hydrocarbons.
\end{abstract}

In the preceding paper (Cecil \& Louis, 1970) the interactions of various proteins with pure $n$-decane were described. During these experiments the sample of decane, which had been purified as described and then kept for several months in the dark at $2^{\circ} \mathrm{C}$, gave results quite different from those obtained with freshly purified decane. It was found that this sample contained, as an impurity, octan-1-ol produced by spontaneous decomposition of the decane. This suggested that small amounts of alcohols could have a considerable effect on protein-hydrocarbon interactions. The experiments described here were carried out both with this sample of impure decane and with pure decane to which known amounts of different alcohols had been added.

\section{MATERIALS}

All materials used in this work are as described in Cecil \& Louis (1970) except for the following.

Decan-1-ol, octan-1-ol and hexan-1-ol. These alcohols were obtained from British Drug Houses Ltd., Poole, Dorset, U.K. They were distilled under reduced pressure and the major fractions that boiled within a range of $1^{\circ} \mathrm{C}$ collected. G.l.c. on a $15 \%$ polypropylene glycol column showed that the alcohols were at least $99.9 \%$ pure.

Miscellaneous alcohols. All other alcohols were obtained from Koch-Light Laboratories Ltd., Colnbrook, Bucks., U.K., who claimed that they were all at least $98 \%$ pure by g.l.c. They were distilled before use.

$\left[{ }^{14} \mathrm{C}\right]$ Decan-1-ol. $\left[{ }^{14} \mathrm{C}\right]$ Decan-1-ol was obtained from the International Chemical and Nuclear Corp., City of Industry, Calif., U.S.A. It was diluted with pure decan1-ol to give a specific radioactivity of $0.02 \mathrm{mCi} / \mathrm{ml}$. The radiochemical purity of the alcohol was claimed to be 99\%. No further purification was attempted. The $\left[{ }^{14} \mathrm{C}\right]-$ decan-1-ol was stored in a Pyrex test tube at $2^{\circ} \mathrm{C}$ in the dark.

Buffer solutions. In experiments where some property of a protein was studied at different $\mathrm{pH}$ values, a stock solution of protein of twice the final concentration was made up in water and the various $\mathrm{pH}$ values were obtained by adding $3 \mathrm{ml}$ of protein solution to $3 \mathrm{ml}$ of $0.2 \mathrm{M}$ buffer solution of the required $\mathrm{pH}$.

The buffer solutions were made up as follows (Dawson, Elliott, Elliott \& Jones, 1969): $\mathrm{pH} 2.0,20 \mathrm{~mm}-\mathrm{HCl}-$ $0.2 \mathrm{M}-\mathrm{NaCl} ; \mathrm{pH3.0}, 0.2 \mathrm{M}$-glycine-11 mm-HCl; $\mathrm{pH} 4.0$, $164 \mathrm{~mm}$-acetic acid-36mM-sodium acetate; pH4.5, $114 \mathrm{~mm}$-acetic acid-86 mM-sodium acetate; $\mathrm{pH}$ 5.0, $60 \mathrm{~mm}$ acetic acid-140 mM-sodium acetate; $\mathrm{pH} 5.5,23 \mathrm{mM}$-acetic acid-177 mM-sodium acetate; $\mathrm{pH} 6.0,24 \mathrm{~mm}-\mathrm{Na}_{2} \mathrm{HPO}_{4}-$ $176 \mathrm{~mm}-\mathrm{NaH}_{2} \mathrm{PO}_{4}$; pH6.5, $63 \mathrm{~mm}-\mathrm{Na}_{2} \mathrm{HPO}_{4}-137 \mathrm{~mm}$ $\mathrm{NaH}_{2} \mathrm{PO}_{4} ; \mathrm{pH} 7.0,122 \mathrm{~mm}-\mathrm{Na}_{2} \mathrm{HPO}_{4}-78 \mathrm{~mm}-\mathrm{NaH}_{2} \mathrm{PO}_{4}$; pH 8.0, 0.2 M-tris-144 mM-HCl; pH9.5, 0.2 M-glycine$78 \mathrm{~mm}-\mathrm{NaOH}$.

\section{APPARATUS AND METHODS}

Ultracentrifugal analysis. Sedimentation coefficients were measured in standard and wedge cells by using a Beckman Spinco model E analytical ultracentrifuge.

Other apparatus and methods. These were as described in Cecil \& Louis (1970).

\section{RESULTS}

Decane ' $O$ '

Some experiments with decane gave results differing from those reported by Cecil \& Louis (1970). The batch of decane that was used for 
these experiments had been purified 4 months previously as described by Cecil \& Louis (1970). Thus it was possible that an impurity had been produced in the decane as a result of spontaneous decomposition. This should have been very unlikely as the decane had been stored at $2^{\circ} \mathrm{C}$ in a Pyrex bottle in the dark. However, an attempt was made to identify the impurity that was giving these anomalous results. Since it was competing with the protein for the surface of the emulsion, it was thought to be a long-chain carbon compound containing a polar end group.

An i.r. spectrum of the decane showed a sharp peak at $2.74 \mu \mathrm{m}$ corresponding to a free hydroxyl stretching frequency. A smaller peak was observed at $9.5 \mu \mathrm{m}$, which is characteristic of the hydroxyl bending vibrations of a primary alcohol. This suggested that the impurity present in the decane was a primary alcohol.

To identify the alcohol or alcohols present, $1 \mu l$ portions of the decane were injected on to g.l.c. columns (a Perkin-Elmer model F11 gas chromatograph was used). Polypropylene glycol and polyethylene glycol succinate ester columns were found to give the best resolution of long-chain alcohols. When the decane was injected on to both columns in turn, two peaks only were observed, one very large, which was shown to be due to the decane, the other much smaller, emerging some time after the decane peak. To identify the smaller peak, samples of pure alcohols in decane were injected on to both columns and the times taken for their peaks to emerge were recorded. The two sets of results are shown in Table 1 . The results obtained with the two columns proved that the alcohol present in the decane was octan-1-ol.

For a given sensitivity setting the area under the peak is proportional to the concentration of the alcohol. Accordingly, various amounts of octanol were dissolved in a given volume of ether and $1 \mu l$

\section{Table 1. G.l.c. of decane ' $O$ ' and of samples of pure} alcohols

Columns: 1 , polypropylene glycol, maintained at $130^{\circ} \mathrm{C}$ with an injection block setting of $4.5 ; 2$, polyethylene glycol succinate ester, maintained at $140^{\circ} \mathrm{C}$ with an injection-block setting of 4.5 .

Time for peaks to emerge after injection (min)
Alcohol

Alcohol present as impurity in decane ' $O$ '

Nonan-1-ol

Octan-1-ol

Heptan-1-ol

$\begin{array}{cc}\text { Column 1 } & \text { Column } 2 \\ 4.20 & 5.50 \\ 7.30 & 8.30 \\ 4.20 & 5.50 \\ 2.30 & 4.00\end{array}$

of each was injected on to the polyethylene glycol succinate ester column and the areas were compared with that from the impure decane sample. In this way the decane was shown to contain $0.25 \%(v / v)$ of octanol.

As a further check that the percentage of octanol in decane had been determined correctly, dilutions of octanol in pure decane were made and their i.r. extinctions at $2.74 \mu \mathrm{m}$ recorded. The percentage of octanol in decane was shown to obey Beer's Law and the amount of octanol present in the impure decane was again found to be $0.25 \%(v / v)$. This solution of $0.25 \%$ octanol in decane is referred to as decane ' $O$ '.

Experiments with pure decane, saturated with ethylene, showed no difference from those performed with pure decane showing that, if any olefin were produced by photo-oxidation of decane, it would be unlikely to give the results observed with decane ' $\mathrm{O}$ '.

The original experiments were repeated with a solution of $0.25 \%$ octanol in decane and the results obtained were identical with those obtained with the impure decane containing octanol.

\section{Adsorption of protein on hydrocarbon-in-water emulsions containing octanol}

When increasing volumes of decane ' $O$ ' were added to a given initial concentration of lysozyme at pH 2.0 it was found that there was a maximum loss of protein from solution when a certain volume of decane had been added. This is illustrated in Fig. 1, curve I; curve II shows the same experiment with pure decane. A similar result was obtained with a $12 \mu \mathrm{M}$ solution of bovine serum albumin at pH 7.0, where the maximum loss of protein from solution occurred with $200 \mu \mathrm{l}$ of decane ' $O$ '. For convenience this volume of decane ' $\mathrm{O}$ ' required to

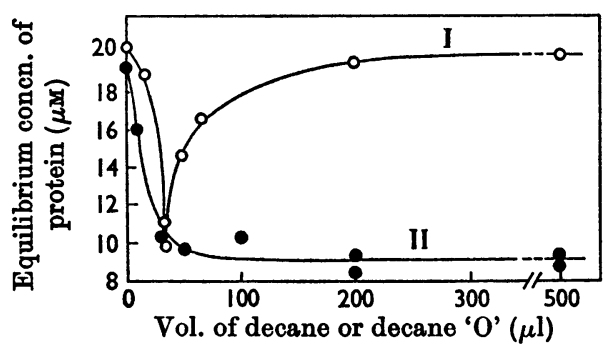

Fig. 1. Equilibrium concentration of lysozyme remaining in solution at $\mathrm{pH} 2.0$ plotted against the volumes of decane ' $O$ ' and decane respectively. Samples $(6 \mathrm{ml})$ of $20 \mu \mathrm{M}$-lysozyme were equilibrated with different volumes of decane ' $O$ ' and decane and the equilibrium concentration of lysozyme was measured. Curve I, decane ' $O$ '; curve II, decane. 
produce the maximum loss of protein from solution is referred to below as the 'volume at the dip'.

It is clear that there are differences in the behaviour of pure decane and decane ' $O$ ' on both sides of the dip; in both cases the presence of octanol causes a decrease in the amount of protein adsorbed, although at the dip itself there is little difference. The addition of an excess of pure decane has no effect on the amount of protein adsorbed, yet addition of an excess of decane ' $O$ ' prevents the adsorption of any protein. This differ: ence can therefore be ascribed entirely to the additional octanol.

Comparison of the behaviour of different proteins. When different proteins were equilibrated with decane ' $O$ ' the volume at the dip was found to vary both with the protein and with its initial concentration. In every case the volume at the dip increased linearly with increasing concentration; with bovine serum albumin and lysozyme this increase reached a limiting value in the concentration range used. Fig. 2. shows the results obtained with lysozyme. With bovine serum albumin the volume at the dip reached a limiting value at a much lower concentration, i.e. $22 \mu \mathrm{M}$. The amount of protein lost from solution (and adsorbed at the interface) fell from about $50 \%$ at the lower concentration (approx. $10 \mu \mathrm{M})$ to about $20 \%$ at the higher concentration

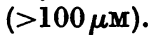

The nature of the layer of protein at the interface is likely to be affected by changes in the conformation of the protein. Bovine serum albumin undergoes a change in conformation, involving an increase in the hydrodynamic volume, below $\mathrm{pH} 4$ (Yang \& Foster, 1954), and this results in a sharp change in the volume at the dip and a more gradual change in the amount of protein lost from solution (Fig. 3). A sample of albumin that had been defatted by the method of Chen (1967) behaved in the same way.

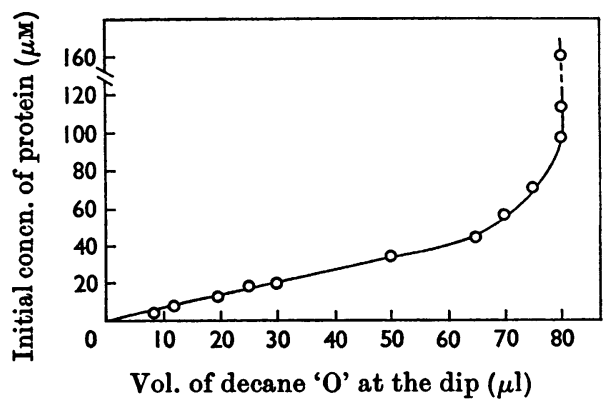

Fig. 2. Volume of decane ' $O$ ' at the dip plotted against the initial concentration of lysozyme at pH 2.0.
Lysozyme is known to dimerize above pH5.56.0 (Sophianopoulos \& van Holde, 1964), and this increase in molecular weight is reflected in a sharp increase in the amount of protein lost from solution at the dip; the effect is greater at higher protein concentration (Fig. 4). There is no accompanying change in the volume at the dip. Sophianopoulos \& van Holde (1964) observed the increase in $8_{20}$ at

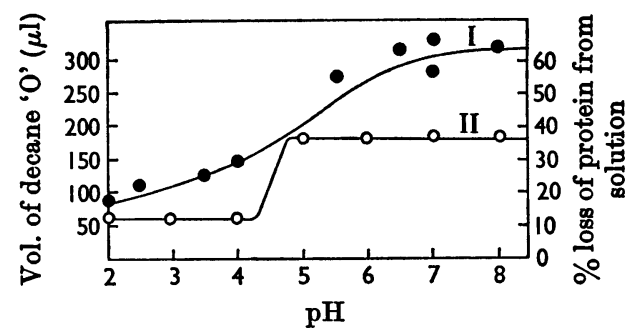

Fig. 3. Volume of decane ' $O$ ' at the dip, together with the percentage loss of bovine serum albumin from solution at the dip, plotted against pH. Curve I, percentage loss; curve II, volume at the dip. The initial concentration of protein was $10 \mu \mathrm{M}$.

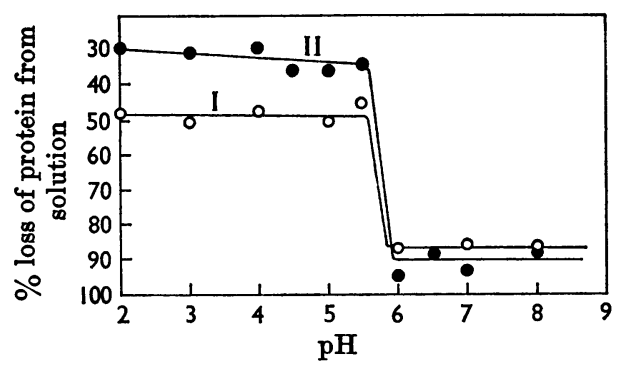

Fig. 4. Percentage loss of lysozyme from solution at the dip plotted against $\mathrm{pH}$. Curve I, initial concentration of lysozyme $19 \mu \mathrm{M}+30 \mu \mathrm{l}$ of decane ' $O$ '; curve II, initial concentration of lysozyme $112 \mu \mathrm{M}+80 \mu \mathrm{l}$ of decane ' $O$ '.

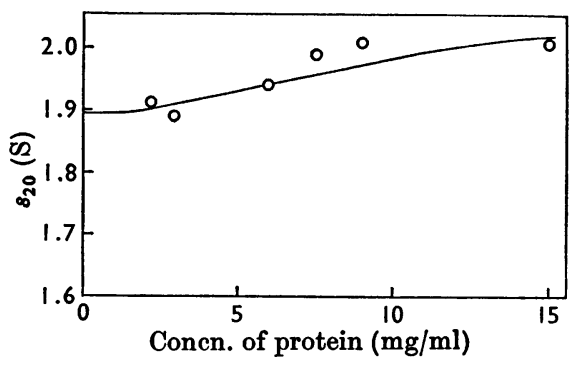

Fig. 5. Variation of the $s_{20}$ value of lysozyme with concentration at $\mathrm{pH}$ 7.0. 
a concentration of $1.5 \%$ whereas the change reported here was observed at a concentration of $0.03 \%$. It was therefore decided to test whether the increase in $s_{20}$ could be observed at lower concentrations. The results at $\mathrm{pH} 7.0$ shown in Fig. 5 indicate that there is no significant increase below a concentration of $0.2 \%$. This apparent discrepancy is discussed below.

The dimerization of lysozyme also affected the way in which adsorbed protein can be removed from the interface. If a solution of lysozyme at any $\mathrm{pH}$ is equilibrated with the volume of decane ' $O$ ' at the dip a proportion of the lysozyme is adsorbed depending on the protein concentration and the $\mathrm{pH}$. If the hydrocarbon phase is then removed by centrifugation and re-equilibrated with $6 \mathrm{ml}$ of $\mathrm{pH} 2.0$ buffer it is found that about $40 \%$ is removed to the aqueous phase; if $\mathrm{pH} 7.0$ buffer is used less than $10 \%$ is removed.

The molecular weight of insulin changes from approx. 12000 at $\mathrm{pH} 2.0$ to approx. 36000 at $\mathrm{pH} 8.0$ (Creeth, 1953). This change is reflected in the fact that when solutions of insulin are equilibrated with decane ' $O$ ' $55 \pm 5 \%$ of the protein is adsorbed at $\mathrm{pH} 2.0-4.0$, whereas at $\mathrm{pH} 7.0-9.5 \quad 80 \pm 5 \%$ is adsorbed.

\section{Binding of decane by protein in solution}

The binding of decane by proteins was investigated with a $0.25 \%$ solution of octanol in either $\left[{ }^{3} \mathrm{H}\right]-$ or $\left[{ }^{14} \mathrm{C}\right]$-decane. As with pure decane (Cecil \& Louis, 1970) binding was detected at $22^{\circ} \mathrm{C}$ with bovine serum albumin, lysozyme and insulin, but not with ribonuclease.

When this radioactive decane ' $O$ ' was used to investigate the binding of decane by various proteins it was found that, for a given volume of decane ' $O$ ', the number of $\mathrm{mol}$ of decane bound/mol of protein increased with decreasing concentration of protein down to about $0.2 \mathrm{mg}$ of protein $/ \mathrm{ml}$, below which the binding decreased sharply. In all these experiments $10 \mu$ l of radioactive decane ' $O$ ' was equilibrated with $6 \mathrm{ml}$ of protein solution at $22^{\circ} \mathrm{C}$ for $24 \mathrm{~h}$ on the wheel. The results are shown in Fig. 6. The reason for this sharp decrease in $\bar{\nu}$ at low concentrations, which does not occur with pure decane (Cecil \& Louis, 1970), is discussed below.

In another series of experiments a $10 \mu \mathrm{M}$ solution of lysozyme at $\mathrm{pH} 2.0$ was equilibrated with different volumes of radioactive decane ' $O$ '. Both $\bar{\nu}$ and the equilibrium concentration of lysozyme were measured and these are shown in Fig. 7 plotted against the volume of decane ' $O$ '. The maximum value of $\bar{\nu}$ occurs when the protein concentration is at a minimum, i.e. at the dip. The binding of decane under these conditions was also

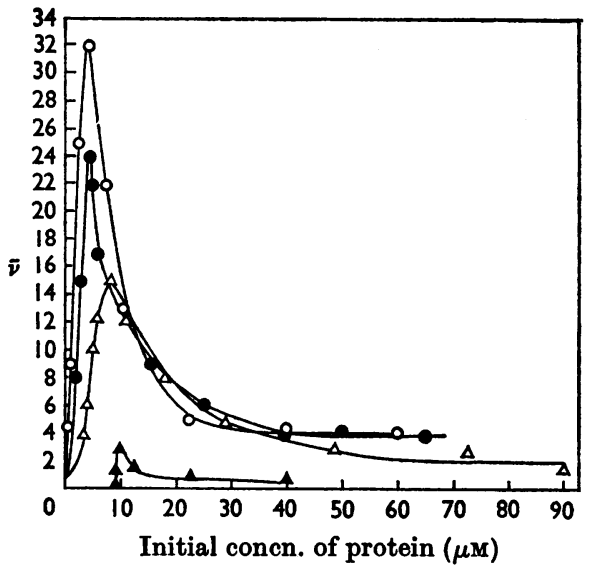

Fig. 6. Number of $\mathrm{mol}$ of decane bound $/ \mathrm{mol}$ of protein $(\bar{v})$ with different protein concentrations. Samples $(6 \mathrm{ml})$ of protein solutions were equilibrated with $10 \mu \mathrm{l}$ of decane ' $O$ ' for $24 \mathrm{~h}$ and $\bar{\nu}$ was measured as described in the text. $\Delta$, Lysozyme at pH $2.0 ; 0$, bovine serum albumin at $\mathrm{pH} 2.0 ; O$, bovine serum albumin at $\mathrm{pH} 6.0 ; \Delta$, insulin at $\mathrm{pH} 2.0$.

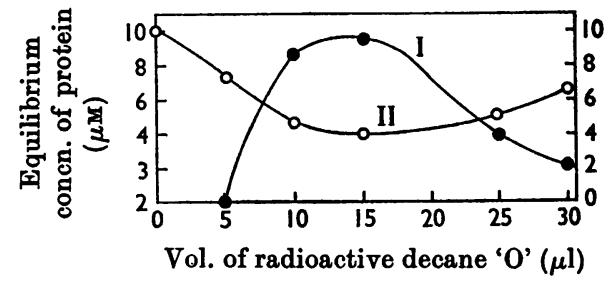

Fig. 7. Number of mol of decane bound/mol of lysozyme (i) at $\mathrm{pH} 2.0$, together with the equilibrium concentration of protein remaining in solution, plotted against the volume of decane ' $O$ ' present. The initial concentration was $10 \mu \mathrm{M}$. Curve I, $\bar{v}$, curve II, equilibrium concentration of protein.

shown to be reversible, as was observed with pure decane (Cecil \& Louis, 1970).

\section{Binding of decanol by protein in solution}

It was of interest to know whether octanol competes with decane for the binding sites on the protein. Unfortunately a sample of radioactive octanol could not be obtained and so $\left[{ }^{14} \mathrm{C}\right]$ decanol was used instead. Samples $(6 \mathrm{ml})$ of various concentrations of bovine serum albumin at $\mathrm{pH} 7.0$ were equilibrated with $10 \mu$ l of radioactive decanol at $22^{\circ} \mathrm{C}$. No emulsion was formed, but the relation between amount of decanol bound and the protein concentration (Fig. 8) was very similar to that obtained with pure decane (Cecil \& Louis, 1970). 


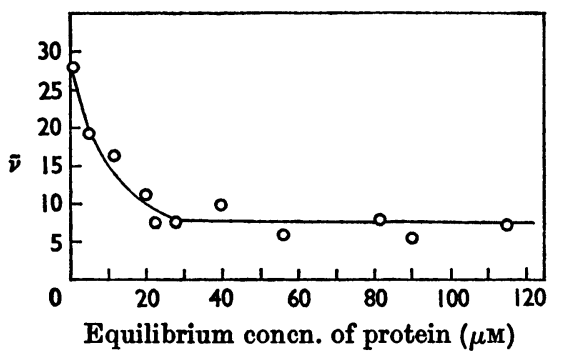

Fig. 8. Number of $\mathrm{mol}$ of decanol bound/mol of bovine serum albumin $(\bar{v})$ at $\mathbf{p H}$ 7.0. Samples $(6 \mathrm{ml})$ of different concentrations of protein were equilibrated with $10 \mu \mathrm{l}$ of radioactive decanol for $24 \mathrm{~h}$.

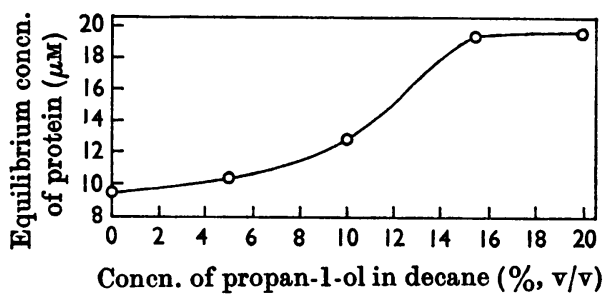

Fig. 9. Concentration of lysozyme remaining in solution at $\mathrm{pH} 2.0$ in equilibrium with $300 \mu \mathrm{l}$ samples of decane containing different amounts of propanol. Samples (6ml) of 19.5 $\mu \mathrm{M}$-protein were used and the equilibrium concentration was plotted against the percentage of propanol in the decane.

It is therefore possible that hydrocarbons and longchain alcohols compete for the same sites on the protein.

\section{Effect of different alcohols on decane-in-water emulsions stabilized by proteins}

The experiments in which solutions of lysozyme were equilibrated with various volumes of decane ' $O$ ' (Fig. 1) showed that, in the presence of an excess of decane ' $O$ ', no protein was lost from solution and no emulsion was formed. This effect was attributed to the octanol present in the system, and it was decided to compare the relative efficiency of other alcohols preventing the adsorption of protein on the hydrocarbon surface. The method used was to equilibrate $6 \mathrm{ml}$ samples of lysozyme solution at $\mathrm{pH} 2.0$ with $300 \mu$ l of decane containing different percentages of the alcohol concerned. Fig. 9 shows the results with propan-1-ol. Similar experiments were carried out with other alcohols, and the minimum percentage of each alcohol that prevented the adsorption of protein is given in
Table 2. Minimum percentages of alcohol in decane required to prevent loss of protein from solution

Samples of $20 \mu \mathrm{M}$-lysozyme at $\mathrm{pH} 2.0$ were equilibrated with $300 \mu$ l of alcohol-in-decane dilutions for $24 \mathrm{~h}$ on the wheel.

$\begin{array}{lc}\text { Alcohol } & \begin{array}{c}\% \text { of alcohol } \\ \text { required }\end{array} \\ \text { Methanol } & 90 \\ \text { Ethanol } & 30 \\ \text { Propan-1-ol } & 15 \\ \text { Butan-1-ol } & 10 \\ \text { Pentan-1-ol } & 2.8 \\ \text { Hexan-1-ol } & 1.6 \\ \text { Heptan-1-ol } & 0.99 \\ \text { Octan-1-ol } & 0.2\end{array}$

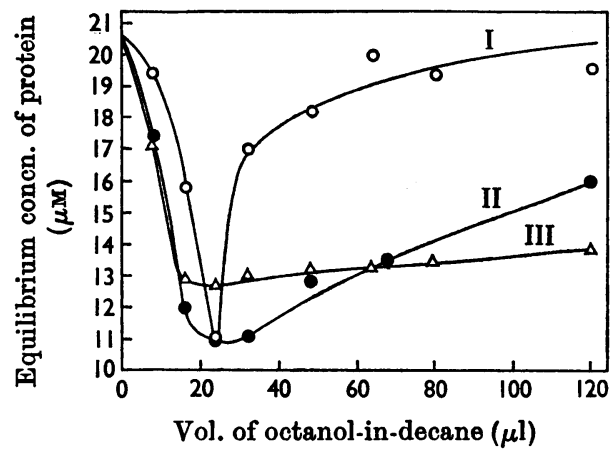

Fig. 10. Equilibrium concentration of lysozyme remaining in solution at $\mathrm{pH} 2.0$ plotted against the volume of different solutions of octanol in decane. Samples $(6 \mathrm{ml})$ of $20.5 \mu \mathrm{M}$-protein were equilibrated with different volumes of octanol-in-decane solution and the equilibrium concentration of protein was measured. Concentration of octanol in decane (v/v): curve I, $1 \%$; curve II, $0.2 \%$; curve III, $0.1 \%$.

Table 2. Experiments with hexan-1-ol, hexan-2-o1 and hexan-3-ol as well as with heptan-1-ol, heptan3-ol and heptan-4-ol showed that the secondary alcohols behaved similarly to the corresponding primary alcohols.

Lysozyme was used for comparing the effects of the different alcohols because its behaviour with alcohol in decane solution is comparatively simple. Fig. 10 shows the effect of varying the percentage of octanol in the decane; the dip becomes progressively sharper as the concentration of octanol is increased, but the volume of decane at the dip remains unchanged. Similar experiments with bovine serum albumin at $\mathrm{pH} 7.0$ showed that the volume at the dip decreases as the percentage of octanol in the decane is increased (Fig. 11). 


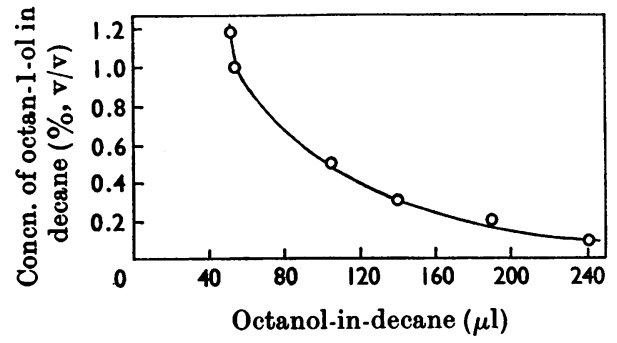

Fig. 11. Volume at the dip of different octanol-in-decane solutions in equilibrium with bovine serum albumin at pH 7.0. Samples $(6 \mathrm{ml})$ of $12.6 \mu \mathrm{M}$-protein were equilibrated with different volumes of different octanol-indecane solutions and the volume at the dip was plotted against the percentage of octanol in decane.

\section{Effect of emulsions on the activity of enzymes}

Both lysozyme and ribonuclease behaved in the same way on emulsions of decane ' $O$ ' as they did on emulsions of pure decane (Cecil \& Louis, 1970). The activity of the enzymes on the emulsion was less than $10 \%$, in solution in equilibrium with decane ' $O$ ' emulsions it was $85 \pm 10 \%$ and after removal of the hydrocarbon phase it was $80 \pm 10 \%$.

\section{DISCUSSION}

This paper is concerned with the effect that alcohols have on the interactions between proteins and hydrocarbons. Because this effect was discovered as the result of an accidental impurity much of the work was carried out with decane ' $O$ ' rather than with predetermined solutions of alcohols in decane.

The general picture of these interactions is similar to those with pure decane, namely that there is an equilibrium between protein in solution in the aqueous phase and that adsorbed on the interface. When alcohols are added to this system they will be distributed between the aqueous and hydrocarbon phases and the interface. They will therefore affect the interactions between protein and hydrocarbon both in the aqueous phase and on the interface.

Octanol does not form emulsions in buffer or in protein solutions; although it is surface-active it does not produce a sufficient decrease in the interfacial free energy to cause emulsification. Nevertheless the difference in Fig. 1 between curve $I$ with decane ' $O$ ' and curve II with pure decane shows that octanol must be present at the interface. With small volumes of decane ' $O$ ', and therefore low concentrations of octanol, the effect is to decrease the amount of protein adsorbed. This effect diminishes with increasing volumes of decane ' $O$ ' until, at the dip, the amount of protein adsorbed is the same as with pure decane. As the volume of decane ' $\mathrm{O}$ ' is increased still further the amount of protein diminishes until, ultimately, none is adsorbed. Therefore under most conditions the presence of hydroxyl groups at the interface decreases the adsorption of protein, but at the dip it does not. This suggests that, at this point, there is a definite stoicheiometric relation between the amount of protein and of octanol at the interface. It is possible that a certain spacing of hydroxyl groups can form a network of hydrogen bonds with the peptide chain and that, when this happens, it balances the tendency of alcohols to prevent the adsorption of proteins.

Mixed-film formation has been the subject of many investigations, especially by Schulman and coworkers (Schulman \& Stenhagen, 1938; Schulman \& Rideal, 1934; Schulman \& Cockbain, 1940; Bowcott \& Schulman, 1955; Rideal, 1945). In most of these cases a long-chain alcohol or cholesterol was present at the interface and a detergent present originally in the aqueous phase. Schulman \& Rideal (1934) as well as Carless \& Hallworth (1968) showed that the two substances were reacting stoicheiometrically at the interface, although by no means all the results for interactions for mixed monolayers indicate that a stoicheiometric relationship is involved (Pankhurst, 1942; Hutchinson, 1948b). Rideal (1945) showed that cholesterol or long-chain fatty acids, when injected under a protein monolayer, formed a complex with the protein and penetrated the monolayer. Cockbain (1953) obtained similar results with bovine serum albumin and sodium dodecyl sulphate. Miles \& Shedlovsky (1944) investigated the interaction of different detergents at both air/water and oil/water interfaces. Their results suggest that in this case also mixed layers occur at the interfaces. Thus the evidence seems to indicate that proteins form some sort of complex with alcohols and detergents at the interface and that this complex must decrease the free energy of the interface by a greater amount than either component alone is able to do.

The possibility of a mixed layer at the interface gives rise to the idea that the protein is bound to the interface by a mixture of hydrophobic interactions between non-polar residues on the protein with the decane and hydrogen bonds between the hydroxyl groups of the octanol with the peptide groups of the protein backbone. These hydrogen bonds will be stronger than those between the same groups in free solution since they are in a nonaqueous environment.

Differences have been observed both with different proteins and with different conformational forms of the same protein. These differences 
can be ascribed to two causes. The spacing of hydrogen-bonding groups in the part of the protein that is in contact with the hydrocarbon phase can differ ; in this case the volume at the dip, representing the optimum proportions of alcohol and protein at the interface, will differ. Alternatively the area occupied by the protein molecule on the interface can differ, in which case the amount of protein adsorbed will be affected.

Bovine serum albumin differs significantly from the other three proteins in that the volume of decane ' $O$ ' at the dip is larger and the protein concentration at which this volume becomes constant is lower. When the $\mathbf{p H}$ of the albumin solutions is decreased below 4.0 there is a conformational change resulting in an increase in the hydrodynamic volume. This causes a sharp fall in the volume at the dip from $180 \mu$ lo $60 \mu \mathrm{l}$, i.e. fewer $\mathrm{mol}$ of octanol $/ \mathrm{mol}$ of protein, and a decrease in the amount of protein adsorbed from $65 \%$ to $18 \%$ of the initial concentration. Moreover, the volume at the dip and the amount of protein lost from solution are the same when a solution of albumin is equilibrated with $0.8 \%$ octanol in decane at pH 7.0 and when a solution of the same concentration at pH 2.0 is equilibrated with $0.25 \%$ octanol in decane (Figs. 3 and 11). Thus the acid form of bovine serum albumin requires only one-third of the amount of octanol and, assuming that the area of the emulsion does not change with $\mathrm{pH}$, occupies three times the area of the normal form.

The properties of bovine serum albumin on hydrocarbon emulsions were investigated by Cockbain (1956), who studied the adsorption of this protein on emulsions of decane in water stabilized by sodium alginate. He concluded that the adsorption was independent of albumin concentration, $\mathrm{pH}$ and ionic strength, and that the albumin layer was monomolecular. The present results with decane ' $O$ ' emulsions are clearly different, but this difference could be accounted for by the presence of sodium alginate in Cockbain's emulsions. Cockbain (1956) pre-emulsified his decane and obtained a value of $1.75 \mathrm{mg}$ of protein $/ \mathrm{m}^{2}$ of decane/water interface. He used an initial concentration of bovine serum albumin of $25 \mu \mathrm{M}$ at $\mathrm{pH} 5.6$ and observed a $45 \%$ loss of protein from the solution; this value is the same as that observed for decane ' $O$ ' emulsions at the dip. In the present work $190 \mu$ l of decane ' $O$ ' was required to give a $45 \%$ loss of protein from $6 \mathrm{ml}$ of a $25 \mu \mathrm{M}$-bovine serum albumin solution at pH5.5, whereas Cockbain (1956) used $80 \mathrm{ml}$ of a protein solution with $20 \mathrm{ml}$ of decane. If the particle sizes are approximately the same in both types of emulsions then only $3.17 \mathrm{ml}$ of decane ' $O$ ' would be required to produce the same loss of protein from solution compared with the $20 \mathrm{ml}$ of decane Cockbain found necessary. By using this volume of $3.17 \mathrm{ml}$ of decane ' $O$ ' the amount of protein $/ \mathrm{m}^{2}$ of interface would come to $11.0 \mathrm{mg}$. This surface concentration of protein is far in excess of that required by a monolayer of protein, indicating that the protein may be adsorbed on decane ' $\mathrm{O}$ ' emulsions in some kind of multilayer. However, the surface of the emulsions obtained by Cockbain (1956) was probably partly covered by sodium alginate.

Lysozyme tends to dimerize above pH5.5-6.0 and this coincides with a sharp increase in the amount of protein adsorbed (Fig. 4); there is no accompanying change in the volume at the dip. The most likely explanation is that, although there is no change in the conformation of the protein in contact with the hydrocarbon phase, two molecules at pH 6.0 occupy the area occupied by one molecule at $\mathrm{pH}$ 2.0. The values of $s_{20}$ given in Fig. 5 show that dimerization does not occur in free solution until a concentration of $2 \mathrm{mg} / \mathrm{ml}(135 \mu \mathrm{M})$ has been reached. The fact that it apparently occurs on the surface at concentrations as low as $20 \mu \mathrm{M}(0.3 \mathrm{mg} / \mathrm{ml})$ suggests that the intermolecular distance at an interface in equilibrium with a $20 \mu \mathrm{M}$ solution must be comparable with that in a $135 \mu \mathrm{M}$ solution.

A similar situation occurs with insulin. Between pH2.0 and 4.0 the molecular weight is approx. 12000 and $55 \pm 5 \%$ of the protein is adsorbed; between pH7.0 and 9.5 the molecular weight is approx. 36000 (Creeth, 1953) and the amount adsorbed rises to $80 \pm 5 \%$. Ribonuclease does not associate or undergo a major change in conformation between pH4.0 and 8.0 and consequently does not show changes in the volume at the dip or in the amount of protein adsorbed in this $\mathrm{pH}$ range.

All four proteins show an increase in the volume at the dip as the initial concentration of the protein is increased; in two cases, bovine serum albumin and lysozyme, this increase stops when a certain concentration is reached. The most likely explanation is that the amount of protein adsorbed per unit area increases with increasing concentration until the available surface is completely covered with a monolayer. The concentration at which this limit is reached will depend on the partition coefficient of the protein between the aqueous phase and the interface. Unfortunately it was not possible to measure the surface area of these emulsions (Cecil \& Louis, 1970) and so this hypothesis cannot be confirmed.

When solutions of bovine serum albumin, lysozyme and insulin were equilibrated with a fixed volume of radioactive decane ' $O$ ' the amount of decane bound increased with decreasing protein concentration and then fell sharply (Fig. 6). Similar experiments with pure decane (Cecil \& Louis, 1970) did not show this sharp fall. However, when different volumes of decane ' $O$ ' were used 

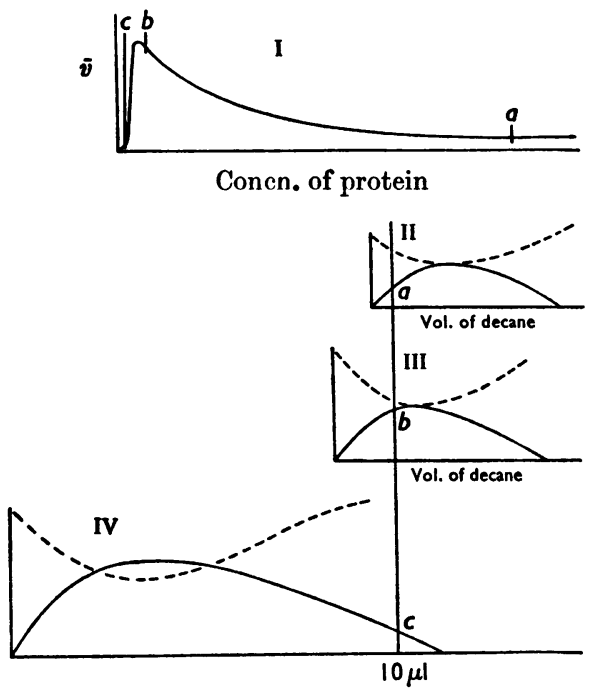

Vol. of decane

Fig. 12. Schematic representation of the number of mol of decane bound $/ \mathrm{mol}$ of protein $(\bar{\nu})$ at different protein concentrations after equilibration with decane ' $O$ '. Curve I shows $\bar{v}$ plotted against protein concentration. Curves II, III and IV show the equivalent of Fig. 7 for points $a, b$ and $c$ on curve $I$, and they show the variation of $\bar{\nu}(-)$ and the equilibrium concentration of protein (---) plotted against the volume of decane ' $O$ ' added. The vertical line shows in each case the point corresponding to $10 \mu$ l of decane.

(Fig. 7) it was found that this sharp decrease in $\bar{\nu}$ corresponded with the volume at the dip.

The relationship between the loss of protein from solution in the presence of decane ' $O$ ' and the binding of decane is shown schematically in Fig. 12 (this corresponds to Fig. 6 in Cecil \& Louis, 1970). Curve I shows the variation of decane binding with various protein concentrations and a fixed volume of decane ' $O$ '. The situations represented by points $a, b$ and $c$ are shown separately in curves II, III and IV in terms of the variation of the no. of mol of decane bound/mol of protein with the volume of decane, at different initial concentrations of protein. At $a$ the volume of decane ' $O$ ' present in relation to the equilibrium concentration of protein is well below that required to give the maximum value of $\bar{\nu}$ and the maximum loss of protein from solution, and so $\bar{\nu}$ is small at this point. At $b$ the volume of decane ' $O$ ' present is now close to the volume necessary to give maximum binding for that concentration of protein (equal to the volume at the dip), so $\bar{\nu}$ rises to a maximum. At $c$ the volume of decane ' $O$ ' is in excess of that required to give the maximum loss of protein from solution and $\bar{\nu}$ is smaller than at $b$ although the concentration of protein is lower (with pure decane this would give a higher value of $\bar{\nu}$; Cecil \& Louis, 1970). A possible explanation for this low value of $\bar{\nu}$ is that the concentration of octanol is relatively high at this point and it may be bound by the protein in preference to decane. The experiments carried out with radioactive decanol support this idea.

The mechanism for the binding process, and the reason for the close relationship between binding and emulsion formation, are thought to be essen. tially the same as those proposed by Cecil \& Louis (1970) for pure decane except that, in this case, octanol has been added to the system.

The type of result illustrated in Fig. 9 provides a method for comparing the effectiveness of different alcohols in their ability to prevent emulsification in the presence of $20 \mu \mathrm{M}$-lysozyme at pH 2.0. The minimum percentages of alcohol in decane required are shown in Table 2; these results have been calculated in terms of molar ratios of alcohols, ethanol being taken as 1.00, in Table 3 .

Cecil \& Thomas (1965) studied the kinetics of the reaction of the 'unreactive' thiol groups of human carboxyhaemoglobin with the sulphitomercuri complex. Because the low reactivity of these groups was thought to be due to their involvement in hydrophobic interactions, the reaction was studied in the presence of different primary alcohols and the logarithm of the first-order rate constant was found to increase linearly with the molar ratio of alcohol to water. The slopes of the line increased with increasing chain length of the alcohol and these slopes were used to compare the relative effectiveness of these alcohols in increasing the reactivity of the thiol groups.

Cecil (1967) found that small glass beads $(0.2 \mathrm{~mm}$ in diameter) treated with dichlorodimethylsilane (which leaves a layer of covalently bound methyl groups on the surface of the glass) form clumps in water but not in alcohols. This was thought to be a 'macro' form of hydrophobic interaction. By comparing the concentrations of different alcohols required to break down the clumps of beads it was possible to obtain, once more, a comparison of the effectiveness of the alcohols.

The values for the three types of experiment are given in Table 3 ; in each case the value for ethanol has been taken as 1.00. A more precise comparison is obtained when the logarithm of the ratio of the effectiveness of the different alcohols (with ethanol taken as 1.00) is plotted against the chain length of the alcohol for both the results reported in this work with emulsions together with those of Cecil \& Thomas (1965) and Cecil (1967), as shown in Fig. 13. The gradient in Fig. 13 indicates that for each additional methylene group the minimum concentration of alcohol required to prevent formation of 
Table 3. Comparison of the effectiveness of different primary $\mathrm{n}$-alcohols in decreasing the strength of different forms of hydrophobic interactions

\begin{tabular}{lccc} 
& \multicolumn{3}{c}{ Relative effectiveness } \\
\cline { 2 - 4 } Methanol & Emulsions* & Glass beads $\dagger$ & SH reactivity \\
Ethanol & 0.23 & 0.40 & 0.32 \\
Propanol-1-ol & 1.00 & 1.00 & 1.00 \\
Butan-1-ol & 2.6 & 3.12 & 2.40 \\
Pentan-1-ol & 4.7 & 12.40 & -16 \\
Hexan-1-ol & 20.0 & - & - \\
Heptan-1-ol & 40.0 & - & - \\
Octan-1-ol & 83.0 & - & - \\
& 250.0 & & \\
& * Data interpolated from Table 2. & \\
& $\dagger$ Data interpolated from Cecil (1967). & \\
& † Data interpolated from Cecil \& Thomas (1965).
\end{tabular}

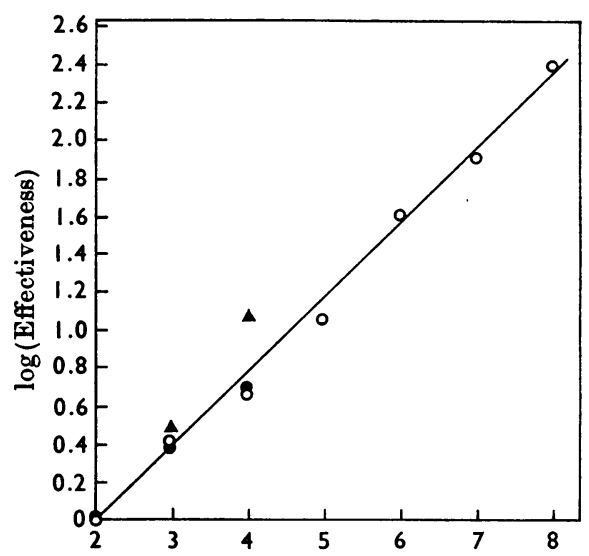

No. of carbon atoms/molecule of alcohol

Fig. 13. Logarithm of the effectiveness of different alcohols in disrupting hydrophobic bonds plotted against the chain length of the alcohol. $O$, Experiments described in the present paper with decane-lysozyme emulsions; - experiments of the reactivity of the thiol groups of human haemoglobin (Cecil \& Thomas, 1965); $\Delta$, experiments with glass beads (Cecil, 1967).

emulsion (i.e. to prevent any loss of protein from solution) was decreased 2.5-fold, which is identical with the value obtained per methylene group on comparison of the reactivities of the 'unreactive' thiol groups of haemoglobin in solutions of different alcohols. The results obtained with decane emulsions confirm that the 'unreactive' thiol groups of haemoglobin are indeed involved in hydrophobic interactions, and suggest that the weakening of these interactions is more likely to be due to specific interactions between the alcohols and the non-polar regions of the haemoglobin rather than a change in the structure of the solvent. Traube (1891) observed that, to obtain a given surface tension for solutions of organic compounds belonging to an homologous series, the concentration required was decreased 3.0-fold for each additional methylene group. However, Hutchinson (1948a) found that the adsorption of $n$-alcohols at an oil/water interface did not obey Traube's rule in that they all gave a close packed area of $20 \AA^{2}$ / molecule. However, Pankhurst (1942), when studying the penetration of monolayers of aliphatic substances or sterols by aliphatic alcohols of chain length from $\mathrm{C}_{4}$ to $\mathrm{C}_{8}$, found that each additional methylene group added to the hydrocarbon chain decreased the concentration required for equal penetration by about 4.5-fold.

There are many instances in Nature where interactions between proteins and non-polar surfaces are involved, cell membranes being an obvious example. Emulsions can be used as, albeit crude, model systems for studying these interactions. This work has shown that hydroxyl groups, in the form of long-chain alcohols, can form mixed films with proteins and have a profound effect on the nature of the protein-hydrocarbon interactions. Further work is needed to see whether other groups can play a similar role.

C.F.L. is indebted to the Science Research Council for support during the period of this work.

\section{REFERENCES}

Bowcott, J. E. \& Schulman, J. H. (1955). Z. Elektrochem. 59, 283.

Carless, J. E. \& Hallworth, G. W. (1968). J. Colloid Sci. 26, 75.

Cecil, R. (1967). Nature, Lond., 214, 369.

Cecil, R. \& Louis, C. F. (1970). Biochem. J. 117, 139.

Cecil, R. \& Thomas, M. A. W. (1965). Nature, Lond., 206, 1317. 
Chen, R. F. (1967). J. biol. Chem. 242, 173.

Cockbain, E. G. (1953). Trans. Faraday Soc. 49, 104.

Cockbain, E. G. (1956). J. Colloid Sci. 11, 575.

Creeth, J. H. (1953). Biochem. J. 53, 41.

Dawson, R. M., Elliott, D. C., Elliott, W. H. \& Jones,

K. M. (1969). Data for Biochemical Research, 2nd ed., p. 475. Oxford: Clarendon Press.

Hutchinson, E. (1948a). J. Colloid Sci. 3, 219.

Hutchinson, E. (1948b). J. Colloid Sci. 3, 413.

Miles, G. D. \& Shedlovsky, L. (1944). J. phys. Chem. 48, 57.

Pankhurst, K. G. (1942). Proc. R. Soc. A, 179, 393.
Rideal, E. K. (1945). J. chem. Soc. p. 423.

Schulman, J. H. \& Cockbain, E. G. (1940). Trans. Faraday Soc. 36, 651.

Schulman, J. H. \& Rideal, E. K. (1934). Proc. R. Soc. B, 122, 29.

Schulman, J. H. \& Stenhagen, E. (1938). Proc. R. Soc. $B, 126,356$.

Sophianopoulos, A. J. \& van Holde, K. E. (1964). J. biol. Chem. 239, 2516.

Traube, J. (1891). Justus Liebigs Annln Chem. 265, 27. Yang, J. T. \& Foster, J. F. (1954). J. Am. chem. Soc. 76, 1588. 